371.671.046.12:811.163.41

https://doi.org/10.18485/sj.2019.24.1.23

МИЛКА В. НИКОЛИЪ*

Универзитет у Крагујевцу

Филолошко-уметнички факултет
Оригинални научни рад Примљен: 11. 09. 2018. Прихваћен: 15. 01. 2019.

\title{
КОМПОЗИЦИЈА И СТРУКТУРА ЛЕКЦИЈЕ У УЏБЕНИЦИМА СРПСКОГ ЈЕЗИКА ЗА ОСНОВНУ ШКОЛУ**
}

У раду се са текстолошког и вербатолошког аспекта разматрају структурне и композиционе одлике лекције у савременим уџбеницима српског језика за основну школу. Циљ је да се опишу и објасне конструкцијска решења у формирању лекције. Корпус чине уџбеници који се користе на почетку предметне наставе. Језичко обликовање лекције схвата се као интегрални део дидактичког обликовања. Посматрају се два начина рашчлањавања лекције: (а) формално (композиционо) рашчлањавање - основна јединица је исказ, а јединица вишег реда је nacyc; (б) смисаоно (структурно) рашчлањавање - основна јединца је дидактичка щелина. Структурираност и дијалогичност, као кључни принципи образовног дизајнирања уџбеника, представљају критеријуме типологије лекција. У корпусу се јављају следећи типови лекција: (1) лекција са појачаним степеном дијалогичности; (2) лекција са појачаним степеном структурираности; (3) лекција са појачаним степеном и дијалогичности и структурираности.

Кључне речи: уџбеник српског језика, лекција, композиција, структура, композициона целина, дидактичка целина, начин излагања.

*milkanik75@gmail.com

** Овај рад написан је у оквиру пројекта Динамика структура савременог српског језика (2011-2019), број 178014, који финансира Министарство просвете, науке и технолошког развоја Републике Србије. 


\section{1. ПРЕДМЕТ И ЦИЉ ИСТРАЖИВАЬА}

Улога уџбеника у образовном процесу није умањена појавом нових наставних средстава, насталих у доба дигитализације, јер уџбеник представља „толико специфичан медиј да с лакоћом опстаје уз све друге новије и софистицираније медије" (Јурић 2004: 58). У овом раду се са текстолошког и вербатолошког аспекта разматрају структурне и композищионе одлике лекције у савременим уџбеницима српског језика за основну школу.

Најновија генерација уџбеника усклађена је са захтевима савременог образовања: „индивидуализација, одгојна димензија, аутодидактичност, разноврсност извора, потицање креативности, рјешавање теоријских и практичних проблема, стварање карте особног сустава знања" (Мијатовић 2004: 15). Очекивано је да су аутори, настојећи да испуне постављене захтеве, изградили различите приступе структури и композищији лекције.

Циљ овог рада је да се на корпусу најновијих уџбеника, зависно од конструкцијских решења која су аутори применили, издвоје, опишу и објасне типови лекција. Корпус чине уџбеници српског језика који се користе на почетку предметне наставе, а који су се појавили после уџбеника Милије Николића (остварења овог аутора схватамо као тип класичног уџбеника).

\section{2. ПРИСТУП ПРОБЛЕМУ}

У психолошко-педагошкој литератури наводе се „минимални жанровски захтеви у погледу образовног дизајна”: (а) „да узорак знања из одређене области буде структуриран као систем знања”; (б) „да се дидактичком обрадом тог садржаја адекватно води и усмерава процес учења" (Пешић 2005б: 377).

С друге стране, према савременим лингвистичким истраживањима, жанр се посматра као: (а) ,апстрактни појам језичког система који учествује у [...] изградњи стилистике конкретних облика комуникације" (Јовановић Симић 2014: 125-126); (б) „знак посматран у посебној перспективи: у перспективи сврхе споразумевања" (Јовановић Симић 2015: 145).

Дидактичко обликовање садржаја представља кључну жанровску одлику уџбеника: уџбенички садржај формира се на такав начин да се ученику пружи подршка у стицању знања. У опису стандарда квалитета уџбеника раздвојено је дидактичко обликовање уџбеничког садржаја од језичког обликоваға (в. Ивић, Пешикан, Антић 2008). У овом раду језичко обликовање посматра се као интегрални део дидактичког обликовања лекције.

Посматрана као текст, лекција се одликује композиционом и структурном сегментацијом. Текстовне јединице дефинишу се на следећи начин: (a) 
„минимална јединица текста јесте појединачни слободни исказ - самостална прагмема способна да у датој ситуацији пренесе известан садржај” (Јовановић, Симић 2009: 602); (б) параграф је „композициона јединица вишег реда која обухвата низ јединица реченичног реда" (Јовановић, Симић 2009: 594).

,'Чланковитост' на једној страни, и потреба за изградњом целовитог смисла, на другој, чине унутрашњу дијалектику текста која омогућава његову егзистенцију као лингвистичке појаве” (Јовановић Симић 2016: 229). У складу с жанровским захтевом да се уџбенички садржај обликује на такав начин да се читаоцу пружи подршка у учењу, разликујемо два начина рашчлањавања текста у уџбенику: (а) формално, тј. композиционио рашлањавање - основна јединица је исказ, а јединица вишег реда је пасус; (б) смисаоно, тј. дидактичко рашчлањавање - основна јединица је дидактичка цุелина. „Принцип параграфирања као више техничка појава ('типографска') укршта се са структурно и смисаоно условљеним сегментирањем, на једној страни, и са композицијом, на другој” (Јовановић Симић 2017: 90-91). Дакле, у нашем разматрању дидактичко обликовање сматра се „структурно и смисаоно условљеним сегментирањем" лекције.

У психолошко-педагошкој литератури указује се да је важан однос експозиторних и индуктивних стратегија у дидактичком обликовњу садржаја лекције (в. Пешић 2009). Експозиторне стратегије омогућавају да се ученику изложе дефиниције, правила, објашњења и сл. Индуктивне стратегије имају улогу у обезбеђивању услова за учење с разумевањем јер ученика усмеравају да самосталним промишљањем дође до дефиниција, правила, објашњења и сл.

Посматрано с лингвистичког аспекта, можемо говорити о различитим начинима излагања у уџбенику. У вербатологији налазимо појмове који се односе на различите начине излагања: (а) описивање; (б) приповедање; (в) расуђивање (расуђивање у ужем смислу, доказивање, оповргавање, уверавање, објашњавање); (г) констатовање или тврђење (Јовановић Симић, Симић 2015: 158-170).

Предмет нашег интересовања јесте однос композиционе (формалне) и структурне (смисаоне) сегментације, што ћемо посматрати на плану односа пасуса и дидактичке изелине. Осмишљајући композицију и структуру лекције, аутори се придржавају двају кључних принципа образовног дизајнирања уџбеника, а то су структурираност и дијалогичност (в. Плут 2003: 241-258). Очекивано је да ће приликом спровођења ових принципа бити остварени различити приступи структури и композицији лекције. Разлике између типова лекција успостављамо помоћу појмова структурираност и дијалогичност, које примењујемо као критеријуме типологије. 


\section{3. РЕЗУЛТАТИ АНАЛИЗЕ}

У складу са педвиђеним обимом рада, резултате анализе приказаћемо на примеру једне лекције, у којој се обрађује исти садржај у сва четири испитивана уџбеника. Изабрали смо компараџију придева, што је захтеван садржај за обраду јер има већи број нових појмова и правила.

\section{1. Лекција са појачаним степеном дијалогичности}

Тип лекције са појачаним степеном дијалогичности налазимо у уџбенику Рајне Драгићевић. Дијалог са читаоцем има различите функције: (а) успостављање сарадње; (б) мотивисање за рад; (в) стварање проблемске ситуације од које почиње обрада садржаја лекције.

Појачавање степена дијалогичности запажа се у насловима рубрика - тако се уместо Вежбање јавља наслов: Хајде да вежбамо! Наслови рубрика реализовани су у облику императива (Запамти!; Уочи!; Подсети се!), као и у облику именице са узвичником (Напомена!). Дијалогичност се појачава и уводним исказом у рубрици у којој се ученику скреће пажња на најчешће грешке (Не мешај придеве и прилоге!; Не мешај прилоге и предлоге!).

Посебну дидактичку вредност има имплицитно остварени дијалог, који је уграђен у текст лекције и који представља саставни део структуре основног уџбеничког текста. Овакав начин остваривања дијалогичности осмишљен је тако да се постигне тзв. вођено учење откривањем (Требјешанин 2001: 82-83). Дакле, дијалошки принцип се интегрише у структурирање лекције.

Употребљава се посебан графички знак за означавање дидактичких целина. Сегментација лекције на пасусе не поклапа се са сегментацијом на дидактичке целине: пасус је обухваћен дидактичком целином.

Размотрићемо лекцију „Променљиве и непроменљиве речи” (Драгићевић 2011: 9-10), у којој дијалогичност посебно долази до изражаја. Редним бројевима означавамо дидактичке целине које су графички издвојене у уџбенику:

(1) Пажљиво прочитај одломак из бајке Месечева принцеза Гроздане Олујућ.

(2) У српском језику постоји десет врста речи. Неке од њих смо већ учили, о некима смо узгред понешто рекли, а о некима ћемо тек говорити. Препознај у тексту речи које припадају оним врстама речи које познајеш.

(3) Хајде да заједно издвојимо све глаголе: [...].

(4) Издвојмо све именице из текста: [...].

(5) А сада придеве: [...].

(6) Понешто знамо и о заменицама: [...].

(7) Вероватно у тексту запажаш и један број: [...].

(8) Преписаћемо речи које су преостале [...].

(9) Неке од побројаних група се понављају. Које су то речи?

Сигурно лако запажаш да се понављао придев Месечев и реч $\partial а[. .$.$] .$ 
Придев Месечев у тексту се појавио три пута: Месечев, Месечев, Месечеву.

Реч $\partial a$ поновљена је четири пута: $\partial a, \partial a, \partial a, \partial a$.

(10) У чему је разлика између ове две речи?

Придев Месечев се појављује у различитим облицима, док се $\partial a$ појављује увек у истом облику.

(11) Да ли је то случајност? Можеш ли да се сетиш неког другог облика у којем се налази реч $\partial a$ ?

Наравно да не можеш. Реч $\partial а$ је непроменљива реч.

(12) Можеш ли да се сетиш још неких облика у којима може да се нађе придев?

То није тешко: месечев, месечевог [...] итд.

Придев месечев је, очигледно, променљива реч.

Речи се у српском језику деле на променљиве и непроменљиве. Непроменљиве имају само један облик, а променљиве имају више облика.

(13) Закључи које су још речи из текста, осим придева, променљиве.

Променљиви су још и глаголи, именице, заменице, бојеви.

У променљиве речи спадају глаголи, именице, придеви, заменице и бројеви.

Остале речи спадају у непроменљиве речи.

Лекција је осмишљена тако да се ученик укључује у рад и да учествује у стварању лекције попуњавајући својим одговорима предивиђене просторе. Са дидактичког становишта, аутор комбинује индуктивне и експозиторне стратегије у структурирању, тј. дидактичком обликовању садржаја.

Аутор континуирано комуницира са читаоцем, настојећи да променом форме исказа унесе динамику: (а) форма са директним обраћањем (Пажљљио прочитај одломак); (б) форма са предикатом у првом лицу множине (Преписаћемо речи које су преостале); (в) упитна форма (У чему је разлика између ове две речи?). Значајни су искази којима се ученик мотивише за рад и истовремено спроводи један од корака у процесу сазнавања: (а) Вероватно у тексту запажаш; (б) Сигурно лако запажаш; (в) Можеш ли да се сетиш [...]? Наравно да не можеш [...]; (г) Можеш ли да се сетии [...]? То није тешко).

У настојању да се доследно спроведе принцип дијалогичности кроз све лекције, важно је спречити фрагментаризацију сазнајног тока, како ученик не би изгубио из вида целину. Аутор је принуђен да проналази економична решења у излагању, како не би дошло до повећања обима лекције. Лекција о променљивим и непроменљивим речима представља успешан пример економичног, као и комуникативно и стилски ефектног излагања.

Размотрићемо и први део лекције о компарацији придева (Драгићевић 2011: 54-58), редним бројевима означавамо дидактичке целине које су графички издвојене у уџбенику:

(1) Овако о лепоти размишља Стојанка Давидовић-Грозданов у песми [...].

А овако о срећи размишља Добрица Ерић у песми [...].

(2) За песникињу нема ничег лепшег од детета. Ништа не може да се пореди са том лепотом. За њу је дете најлепша лепота. Размисли о лепим стварима, упореди их и одговори шта је за тебе најлепше. 
Бића, ствари и појаве очигледно могу да се пореде по степену изражености заједничких особина.

Да бисмо упоредили и језички изразили степен неког својства код више бића, ствари или појава, користимо се поређењем придева или компарацијом.

Лепо је, како мисли Добрица Ерић, бити у друштву дрвећа. Због тога можемо рећи да је дрворед леп, да је парк лепши, јер је у њему више дрвећа, а да је шума најлепша, јер је у њој највише дрвећа.

Аутомобил је брз, авион је бржи од аутомобила, ракета је најбржа. Дакле, сва три предмета имају својство брзине, али је код сваког од њих оно изражено у различитом степену.

(3) Леп - лепши - најлепши, брз - бржи - најбржи представљају примере за компарацију придева. Наведи још примера.

У овом делу лекције постоји један кључни појам - компарација - до којег се долази у другој од наведене три дидактичке целине. Већи део ове, друге по реду, дидактичке целине одликује се уџбеничком нарацијом:

(a) У првом пасусу, недостатак логичког извођења, које је карактеристично за експликативни тип текстовне структуре, надокнађује се реторичким поступком понављања речи лепота и леп у различитим облицима (3а песникињу нема ничег лепшег од детета. Ништа не може да се пореди са том лепотом. За юу је дете најлепша лепота. Размисли о лепим стварима, упореди их и одговори шта је за тебе најлепше). Реторичка средства нису страна научном односно уџбеничком тексту, њима се доприноси истицању битних детаља, нијансирању смисла, поентирању и сл. (Симић, Јовановић 2002: 120). Поједине реторичке фигуре (текстостилеми) омогућавају успостављање смисаоних веза између текстовних сегмената (в. Ковачевић 2015: 295-319).

(б) У другом пасусу наводи се тврдња у којој се сумира претходно речено и најављује закључак (Бића, ствари и појаве очигледно могу да се пореде). Трећи пасус (реализован једним исказом) доноси објашњење појма компарације.

(в) Четврти пасус одликује се неуобичајеним начином излагања за уџбеник, што опет доприноси стилском ефекту излагања, изводи читаоца из аутоматизма перцепције, али се донекле удаљава од експликативног развијања теме (Лепо је, како мисли Добрица Ерић, бити у друштву дрвећа).

(г) Пети пасус донекле се враћа логичком извођењу - у првом исказу се наводе појадиначни примери, да би се у другом исказу спровела генерализација (Дакле, сва три предмета имају својство брзине).

Овакав приступ формирању лекције одликује се живописним и динамичним језичким изразом који одступа од уобичајеног уџбеничког подстила и зато је привлачан читаоцу. Остварује се моделовање текста према адресату, као и интеракција уџбеника са учеником у својеврсном виртуелном дијалогу. 


\section{2. Лекција са појачаним степеном структурираности}

Тип лекције са појачаним степеном структурираности налазимо у уџбеницима Весне Ломпар и Јелене Срдић. На графичком (визуелном) плану доминира подела на дидактичке целине, док у другом плану остаје подела на пасусе. Дидактичка целина је надређена пасусу и представља истовремено и композициону целину (обухвата један или више пасуса).

Сегментација лекције на дидактичке целине изразито је наглашена на визуелном плану: (а) разноврсним ликовно-графичким елементима, чијим се доследним понављањем у лекцијама успоставља одређена парадигма у структурирању садржаја (уоквиравање делова садржаја, боја слова, иконице); (б) просторним раздвајањем дидактичких целина или њихових делова (уношењем белине између сегмената лекције); (в) поднасловима који се односе на уже тематске целине (Грађење компаратива, Грађење суперлатива).

Примена ликовно-графичких средстава омогућила је овим уџбеницима да у извесној мери изађу из линеарног транспоновања садржаја. На пример, садржај о грађењу компаратива распоређен је у два ступца, од којих је један уоквирен, при чему постоје различита решења: (а) уоквирени садржај може бити примаран (наведен је у првом ступцу), а поред оквира су објашњења (в. Срдић 2016: 51); (б) уоквирени садржај може доносити додатне информације (наведен је у другом ступцу), уз примарни садржај који није уоквирен (в. Ломпар 2016: 34).

Комбиновање текстовног и вантекстовног транспоновања садржаја јесте жанровска одлика уџбеника, а на аутору је да осмисли одговарајућа конструкцијска решења. У типу лекције са појачаном дијалогичношћу вербални начин презентовања градива представља најкреативнији аспект овог приступа формирању лекције. У типу лекције са појачаном структурираношћу вантекстовни елементи представљају саставни део структуре. Стваралачка инвенција аутора, у овом случају, огледа се у избору вантекстовних елемената и начину њиховог укључивања у дидактичко обликовање.

Тешкоће са којима се суочава аутор у овом приступу тичу се губитка простора за дијалог, што води ка доминацији експозиторних стратегија у дидактичком обликовању садржаја. То се запажа у следећим одломцима из лекције о компарацији придева, где смо редним бројевима означили дидактичке целине које су издвојене у уџбеницима.

Одломак из уџбеника Јелене Срдић (2016: 50) показује да аутор настоји да применом индуктивне стратегије укључи ученика у излагање садржаја. Након тога, садржај се преноси у трећем лицу, а ученик не учествује у разматрању: 
(1) Шта су придеви? Наведи неколико придева. Како се добија граматичка основа именица и придева?

(2) Упореди придеве у следећим речима: леп (човек), лепши (човек), најлепши (човек) [...].

По чему су ови придеви слични? Какву особину исказује други придев у низу у односу на први придев? А какву особину трећи придев у односу на други?

(3) Овим придевима се, заправо, пореде особине појмова уз које они стоје, нпр. колико је човек леп - да ли је лепши (од неког) или је најлепши (од свих). Таква особина описних придев назива се компарација.

(4) Компарацију чине: [...]

У одломку из уџбеника Весне Ломпар (2016: 32-33) запажа се настојање да се излагањем у првом лицу множине, карактеристичним за жанр уџбеника (,инклузивно ми”), ученик укључи у разматрање:

(1) Сваки описни придев означава особину у некој мери: Милан је висок.

Ако желимо да покажемо да је та особина изражена у већој мери, користићемо исти придев у другом облику: Иван је виши од Милана.

Можемо истим придевом показати да је та особина изражена у највећој мери: Марко је највиши у разреду.

(2) Бића, предмете и појаве можемо поредити по томе да ли је нека њихова заједничка особина јаче или слабије изражена.

Ако се та особина само казује придевом, кажемо да је он у основном облику - позитиву (брз).

Ако се придевом казује да је та особина јаче изражена у односу на исту особину другог појма са којим се пореди, кажемо да је придев у компаративу (бржи).

Ако се придевом казује да је та особина најјаче изражена у односу на исту особину свих појмова са којим се пореди, кажемо да је придев у суперлативу (најбржи).

(3) Промена описних придева према степену особине коју означавају назива се компарација. Придев може бити у: позитиву, компаративу или суперлативу.

Приликом објашњавања појмова позитива, компаратива и суперлатива анафорски су употребљене три паралелне реченичне структуре са одређеним истоветним деловима (Ако се [...], кажемо да је [...]). То доприноси: (а) повезивању текстовних сегемента; (б) појачању структурираности. Условне реченице омогућавају да се постигне експликативни тип текстовне структуре.

Овакав приступ у формирању лекције омогућава ученику да, уз властити мисаони и радни напор, изграђује конструкцију знања јер усваја не само садржај, него и концепт организације садржаја. Савремени графички дизајн омогућава аутору да приближи уџбеник медијском окружењу данашњег ученика (в. Матијевић 2004).

\section{3. Лекција и са појачаним степеном дијалогичности и појачаним степеном структурираности}

Овај тип лекције јавља се у уџбенику Милоша Ковачевића и Миланке Бабић, у којем су појачана оба принципа образовног дизајнирања лекције. 
Структурираност постоји не само на унутрашњем (смисаоном) плану, него и на спољашњем (визуелном) плану, тако што је свака дидактичка целина издвојена оквиром. Дидактичка целина представља истовремено и композициону целину која је надређена пасусу (обухвата један или више пасуса). Употребљена су додатна ликовно-графичка средства (боја слова, иконице), којима се указује на дидактичку функцију појединих структурних целина. На тај начин спроведена је својеврсна рубрикација целокупног садржаја лекције. Тиме се одступа од уобичајеног приступа формирању лекције, који подразумева да се један део основног уџбеничког текста оставља изван рубрика. Заступљене су рубрике: (а) лингвометодички текст; (б) питања, задаци и налози; (в) објашњавање; (г) дефиниција; (г) навођење граматичког или правописног правила; (ђ) садржај на који треба посебно обратити пажњу.

Дијалогичност је остварена: (а) на формалном плану - спроводи се упитним и узвичним исказима; (б) на дубинском плану основног уџбеничког текста - постигнута је интелектуално подстицајним начином транспоновања садржаја. Дијалог са читаоцем континуирано тече од почетка до краја лекције. Директни одговори нису дати за сва питања, што доприноси сузбијању мисаоне инертности приликом читања: да би читалац успешно наставио са савладавањем садржаја, неопходно је да одговори на свако питање.

Наводимо одломке из лекције у којој се обрађује компарација придева, а редним бројевима означавамо дидактичке целине које су графички издвојене у уџбенику. Први део лекције омогућава ученику да усвоји појмове позитива, компаратива и суперлатива (Ковачевић, Бабић 2016: 65-68):

(1) О чему пјесник пјева у првој пјесми? Уочи како писац развија пјесму тако што ћеш издвојити прилошке одредбе за мјесто у свакој строфи. Зашто боју потока различито одређују јелен, зеко, ластавица, лептир и срна?

О чему се пјева у другој, народној пјесми? Чему се чуди дјевојка? Слаже ли се риба с дјевојчиним мишљењем?

О чему пјева пјсеник у трећој строфи? Како си разумио завршетак пјесме? Како се пишу називи планета: малим или великим почетним словом?

(2) Подвуци придјеве у све три пјесме. Разликују ли се они по облику? Уочи да ли су у истом облику употријебљени придјеви у сљедећа три стиха из сваке од наведених пјесама. Употребљавају ли се ти придјеви само у наведеним облицима? [...]

(3) У свакој реченици навели смо по три именице којима се означавају различити појмови. У свакој реченици појмови имају исту особину: у првој поток, ливада и шума имају зелену боју. У другој коњ, птица и очи имају особину да су брзи, а у трећој се Меркуру, Земљи и Сунцу приписује величина.

Јесу ли те особине означене истим обликом пријдева? Имају ли појмови којима се приписује иста особина ту особину у истом степену (истој количини)? Како се називају ти различити степени особине исказани различитим облицима придјева? [...]

(4) Поређење два, три или више бића или предмета према истој заједничкој особини која се јавља у различитим степенима назива се компарација (поређење) придјева. Компарацију имају само описни придјеви.

(5) У колико различитих степена је изражена особина зеленила, брзине и величине у наведеним примјерима? Како се ти степени особине називају? 
(6) Основни облик придјева назива се позитив [...].

Први поредбени степен је компаратив и њим се означава да неко или нешто има особину у вишем степену (већој количини) од оне изражене позитивом [...].

Други поредбени степен је суперлатив и њим се означава да неко или нешто има особину у највишем степену (највећој количини) од оне изражене позитивом [...].

Дидактичке целине су дате у линеарном низу, као у типу лекције у којем доминира дијалогичност. Дидактичко обликовање садржаја базирано је на проблемском дискурсу (в. Пешић 2005а):

(a) У прве три структурне целине доминирају упитни искази, једино се на почетку треће целине користи нарација као начин излагања. У четвртој структурној целини дефинише се појам компарације; дакле, ученик долази до овог појма након што самосталним радом поступно одговори на сва питања.

(б) У првом пасусу треће дидактичке целине комбинују се два начина излагања - нарација у првом исказу и дескрипција у друга два исказа. Прва два исказа у овом пасусу почињу истом синтагмом, а у другом делу другог исказа и у трећем исказу понавља се структура те синтагме: $У$ свакој реченици навели смо [...]. У свакој реченици појмови имају исту особину: у првој [реченици] поток, ливада и шума [...]. У другој [реченици] кою, птица, очи [...], a y трећој [реченици] Меркуру, Земљи и Суниу [...]. Дакле, структура исказа пружа додатну у подршку у учењу.

(в) У четвртој дидактичкој целини дефинише се појам компарације; пета целина садржи питања којима се најављују нови појмови; у шестој целини дефинишу се три нова појма (позитив, компаратив и суперлатив).

Дидактички циљ другог дела лекције јесте усвајање правила о грађењу компаратива и суперлатива (Ковачевић, Бабић 2016: 68-69):

(1) У првој пјесми („Какве је боје поток”) употријебљени су само облици позитива придјева. У другој („Риба и дјевојка”) употријебљени су само компаративи придјева. Хајде да заједно закључимо - на основу наведених примјера - како се творе (граде) компаратив и суперлатив придјева!

(2) Компаратив се твори када се на позитив додају наставци: -ији, -ји или -ши.

Највећи број описних придјева, међу којима су сви они који имају три или више слогова, твори компаратив додавањем наставка -ији на основу добијену од облика позитива одбијањем генитивног наставка: [...].

(3) Одреди позитив придјева у пјесми „Риба и дјевојка” и покажи на који су начин грађени компаративи употријебљени и тој пјесми. Како гласи исправан облик компаратива придјева висок? (Пази: нису исправни облици височији ни вишљи!)

(4) Суперлатив се од свих описних придјева гради тако што се испред облика компаратива дода ријечца нај [...].

(5) У пјесми „Сунчев систем” придјеви су употријебељени само у облику суперлатива. Наведи за те придјеве облике позитива и компаратива!

Обрати пажњу на правопис! Како се пише суперлатив кад придјев почиње гласом (сугласником) $\mathbf{j}$ ?

Ако придјев почиње сугласником $\mathbf{j}$, онда се у суперлативу пишу оба $\mathbf{j}$ (и оно из ријечце нај и оно којим почиње компаратив придјева) [...]. 
Наведени одломак показује да се у дидактичком обликовању садржаја смењују индуктивне и експозиторне стратегије, као и да се оне примењују у пасусима малог обима. То доприноси динамици у транспоновању садржаја, а самим тим и ефикаснијем стицању знања.

Ученику се пружа додатна подршка у учењу: (а) указивањем на начин обављања одређене активности (Уочи како писаи развија пјесму тако што ћеш издвојити прилошке одредбе [...]; Хајде да заједно закључимо-на основу наведених примјера - како се творе (граде) компаратив и суперлатив придјева!); (б) упућивањем савета (Пази: нису исправни облици височији ни вишльи!; Обрати пажюу на правопис!).

Дијалогичност се појачава језичким средствима типичним за жанр уџбеника: (а) директно обраћање (друго лице једнине); (б) „инклузивно ми” (прво лице множине); (в) узвична интонација. Ови поступци у језичком обликовању лекције доприносе побољшању комуникације и интеракције између уџбеника и ученика.

\section{4. ЗАКЉУЧАК}

Анализа уџбеника српског језика који се користе на почетку предметне наставе показала је да на структуру и композищију лекције утиче начин на који аутор примењује принципе структурираности и дијалогичности. У погледу остваривања кључних принципа образовног дизајнирања уџбеника, издвајају се три приступа формирању лекције: (1) лекција са појачаним степеном дијалогичности; (2) лекција са појачаним степеном структурираности; (3) лекција са појачаним степеном и дијалогичности и структурираности.

У погледу односа композиционе (формалне) и структурне (смисаоне) сегментације, аутори најновијих уџбеника јасно издвајају дидактичку целину у односу на $n a c y c$. Дакле, дидактичка целина се препознаје у лекцији и као структурна и као композициона јединица.

Сваки од наведених приступа у образовном дизајнирању лекције подразумева одређене тешкоће које треба савладати: (а) ако доминира принцип дијалогичности, аутор ће имати задатак да „укроти” текст; (б) ако доминира принцип структурираности, аутор ће имати задатак да „укроти” вантекстовне елементе и да се одупре изазову савременог графичког дизајнирања.

Да би се спровео принцип индивидуализације у образовном процесу, пожељно је да се обезбеде различити типови уџбеника. Очекивано је да ученицима одговарају различити приступи обликовању лекције (зависно од индивидуалних когнитивних карактеристика ученика, његовог стила учења, интересовања и др.). 


\section{ИЗВОРИ}

Драгићевић 2011: Рајна Драгићевић, Српски језик и језичка култура за 5. разред основне школе, Београд: Завод за уџбенике.

Ломпар 2016: Весна Ломпар, Српски језик за 5. разред основне школе, Београд: Klett.

Ковачевић, Бабић 2016: Милош Ковачевић, Миланка Бабић, Српски језик и језичка култура за 6. разред основне школе, Источно Ново Сарајево: Завод за уџбенике.

Срдић 2016: Јелена Срдић, Дар речи. Граматика за пети разред основне школе, Београд: Нови Логос.

\section{ЛИТЕРАТУРА}

Ивић, Пешикан, Антић 2008: Иван Ивић, Ана Пешикан, Слободанка Антић, Водич за добар уцбеник - Општи стандарди квалитета уибеника, Нови Сад: Платонеум.

Јовановић, Симић 2009: Јелена Јовановић, Радоје Симић, Текст као језичка и комуникацијска структура, Српски језик, XIV/1-2, Београд, 591-628.

Јовановић Симић 2014: Јелена Јовановић Симић, О жанристици (генологији) као лингвистичкој дисциплини, Филолог, 9, Бања Лука, 116-127.

Јовановић Симић 2015: Јелена Јовановић Симић, 'Жанр' и структура прозног текста, Српски језик, XX/1-2, Београд, 137-155.

Јовановић Симић 2016: Јелена Јовановић Симић, Напомене о структури текста, Кюижевност и језик, LXIII/3-4, Београд, 229-242.

Јовановић Симић 2017: Јелена Јовановић Симић, О композицији текста са лингвистичког гледишта, Српски језик, XXII/1-2, Београд, 75-93.

Јовановић Симић, Симић 2015: Јелена Јовановић Симић, Радоје Симић, Вербатологија (основи науке о вербализацији света), Београд: НДСЈ, Јасен.

Јурић 2004: Vladimir Jurić, Može li udžbenik podržati otvorenost nastave, $u$ : S. Halačev (ur.), Udžbenik i virtuelno okruženje, Zagreb: Školska knjga, 55-60. 
Ковачевић 2015: Милош Ковачевић, Стилистика и граматика стилских фигура, Београд: Јасен.

Матијевић 2004: Milan Matijević, Udžbenik u novom medijskom okruženju, $u$ : S. Halačev (ur.), Udžbenik i virtuelno okruženje, Zagreb: Školska knjga, 73-82.

Мијатовић 2004: Antun Mijatović, Treća generacija udžbenika, $u$ : S. Halačev (ur.), Udžbenik $i$ virtuelno okruženje, Zagreb: Školska knjga, 11-21.

Пешић 2005a: Jelena Pešić, Problemski diskurs udžbenika, Psihologija, 38/3, Beograd, 225-237.

Пешић 2005б: Jelena Pešić, Sociokulturni pristup udžbeniku, Psihologija, 38/4, Beograd, 369-381.

Пешић 2009: Јелена Пешић, Подршка учењу с разумевањем и стратегије дидактичког обликовања уџбеника, Иновације у настави, 22/4, Београд, 40-49.

Плут 2003: Дијана Плут, Уибеник као културно-потпорни систем, Београд: Завод за уџбенике, Институт за психологију.

Симић, Јовановић 2002: Радоје Симић, Јелена Јовановић, Основи теорије функиионалних стилова, Београд: НДСЈ, Јасен.

Симић, Јовановић Симић 2014: Радоје Симић, Јелена Јовановић Симић, О наратологији (наративистици) данас, Наслеђе, 27, Крагујевац, 95-103.

Требјешанин 2001: Биљана Требјешанин, Облици учења у уџбенику, $y$ : Б. Требјешанин, Д. Лазаревић (прир.), Савремени основношколски уибеник, Београд: Завод за уџбенике.

\section{LESSON COMPOSITION AND STRUCTURE IN THE SERBIAN LANGUAGE TEXTBOOKS FOR ELEMENTERY SCHOOL}

\section{Summary}

In this paper, the structural and compositional features of the lesson in contemporary textbooks of the Serbian language for elementary school are disscussed. The aim is to identify, describe and explain types of lessons, depending on the construction solutions that the authors have applied. Language forming of the lesson is con as an integral part of didactic design. The lesson is viewed as a text unit, which is characterized by compositional and structural segmentation. Two ways of segmenting the text are in question: (a) formal (compositional) division; (b) meaningful (structural) division. The key principles for educational 
textbook design are structurality and dialogue. It is expected that the authors, in an effort to meet these requirements, will devise different solutions in the structure and composition of the lesson. The analysis has shown that the following types of lessons can be distinguished: (a) the oldest type of lesson among contemporary textbooks; (b) a lesson with an enhanced degree of dialogue; (v) lesson with an enhanced level of structure; (g) lessons with increased degree of dialogue and with increased degree of structure.

Key words: Serbian language textbook, lesson, composition, structure, compositional unity, didactic unity, presentation type.

Milka V. Nikolić 